\title{
М.Н. Потёмкина
}

\section{ЭКОНОМИЧЕСКАЯ ПРЕСТУПНОСТЬ В МАГНИТОГОРСКЕ В ГОДЫ ВЕЛИКОЙ ОТЕЧЕСТВЕННОЙ ВОЙНЫ: ИНФОРМАЦИОННЫЙ ПОТЕНЦИАЛ ИСТОРИЧЕСКИХ ИСТОЧНИКОВ ${ }^{1}$}

В статье рассмотрены источники по истории экономической преступности в важном промышленном тыловом городе - Магнитогорске в годы Великой Отечественной войны. Документальные материалы центральных и местных архивов, а также публикации в местной прессе военного периода содержат сведения, которые могут быть использованы в научных целях при изучении проблем экономической преступности в советском тылу в экстремальных условиях войны. Эти материалы содержат статистические данные, описания различных видов экономических преступлений, анализ факторов их воспроизводства, изменение законодательной базы государственного противодействия преступности. Сделан вывод о том, что, несмотря на неполную сохранность и рассредоточенность документов по различным архивам и фондам, исследованные материалы обладают высокой информативной ценностью, так что их научное использование будет способствовать комплексному раскрытию проблемы состояния экономической преступности в тыловом монопромышленном городе оборонного значения.

Ключевые слова: исторический источник, экономическая преступность, Великая Отечественная война, Магнитогорск, архивный документ, периодическая печать.

DOI: 10.35634/2412-9534-2019-29-4-656-659

Российская действительность демонстрирует увеличение и разнообразие преступлений в экономической сфере. История свидетельствует, что криминогенная обстановка в обществе серьёзно обостряется в эпохи революций, войн и кардинальных реформ. В этом ключе исторический опыт форм преступной деятельности, факторов её воспроизводства и особенностей государственного противодействия преступности в экстремальных условиях Великой Отечественной войны представляет особый исследовательский интерес. Одним из ведущих промышленных центров оборонного значения в годы войны стал Магнитогорск - город в Челябинской области с населением (данные на 1 января 1945 г.) в 224 тыс. жителей [5, ф. 234, оп. 19, д. 1, л. 64], построенный в период индустриализации и располагавшийся в глубоком советском тылу.

Тема экономической преступности в Магнитогорске в экстремальных условиях военного времени получила отражение в фондах центральных, областных и муниципальных архивов и в региональной периодической печати. Материалы эти рассеяны в фондах Наркомата госконтроля, НКВД, Прокуратуры, народных судов, горкома партии и др. Обратимся к характеристике этих материалов.

Делопроизводственные документы, отражающие ход и итоги проверок промышленных предприятий Наркомата чёрной металлургии с целью проверки учёта хранения и использования вспомогательных материалов имеются в Государственном архиве Российской Федерации (фонд Р-83100 - Наркомат госконтроля СССР). Проверки были организованы во исполнение Постановления ГКО № 2780 от 22 января 1943 г. «Об усилении борьбы с расхищением и разбазариванием продовольственных и промышленных товаров». На Магнитогорском металлургическом комбинате (ММК) такая проверка была проведена главным контролёром Наркомата госконтроля СССР по Наркомчермету А. Павельевым в августе - сентябре 1944 г. В деле присутствуют докладные записки о результатах проверки и выявленных нарушениях; а также объяснительные начальника снабжения ММК Козлова и директора ММК Г. И. Носова; предписание проверить и аннулировать договоры, противоречившие закону; текст приказа по ММК директора Г. И. Носова от 4 декабря 1944 г. № 18. Красноречивы строки в объяснительной директора ММК Г. И. Носова: «Считаю, что допущенный расход 500 тонн бензола вызвался важнейшими государственными интересами поставки металла военной промышленности и обеспечения трудящихся комбината продовольствием» $[2$, ф. Р-83100, оп. 18 , д. 30, л. 34]. Такого рода архивные документы позволяют исследовать и проследить управленческие практики на тыловых оборонных предприятиях, понять масштабы и причины нарушений социалистической законности, на которые вынуждены были идти руководители предприятий монопромышленных городов советского тыла ради выполнения оборонных заказов и поддержания жизнеспособности населения города.

\footnotetext{
${ }^{1}$ Исследование выполнено при финансовой поддержке РФФИ в рамках научного проекта № 19-09-00185.
} 
Экономическая преступность в Магнитогорске в годы Великой Отечественной войны...

657 СЕРИЯ ИСТОРИЯ И ФИЛОЛОГИЯ

2019. Т. 29, вып. 4

Документы, содержащие материал статистического и аналитического характера прокурорского надзора за исполнением законности, отложились в фонде А-461 - Прокуратура РСФСР. Это - акты, справки, докладные записки проверки работы прокуратуры Челябинской области [2, ф. А-461, оп. 8 , д. 208, 209, 414, 536, 613, 661, 872].

Объединённый государственный архив Челябинской области также содержит документы по истории экономической преступности в Магнитогорске в годы Великой Отечественной войны, представляющие научный интерес. Особое внимание обратим на материалы партийных фондов, поскольку в основу советской цивилизационной модели была заложена идея единой руководящей и главенствующей партии, которая выполняла роль стержня политической системы, дублировала функции государственных органов власти и управления и осуществляла тотальный контроль за всеми сферами жизни общества. В фонде П-234 - Магнитогорский горком ВКП(б) отложились документы, отражающие проблемы экономической преступности в городе и меры борьбы с ней: помесячные, поквартальные, погодовые справки о состоянии преступности в городе и мерах борьбы с ней, докладные записки о работе органов прокуратуры Магнитогорска, о практических мероприятиях по оказанию помощи органам милиции города в борьбе с преступностью, информационные справки (о борьбе с расхитителями социалистической собственности, о преступности среди несовершеннолетних) $[5$, ф. П-234, оп. 17, д. 88; оп. 18 , д. 14; оп. 19, д. 78].

Справки «О состоянии преступности в городе» поступали регулярно под грифом «совершенно секретно» от заместителя начальника ГУВД на имя секретаря горкома ВКП(б) и, как правило, содержали следующую информацию: статистика общего количества уголовных проявлений за отчётный период (напр., с раскладкой по месяцам); статистика наиболее характерных видов преступлений; процент раскрываемости по основным видам преступлений; характеристика привлечённых к ответственности по половому, возрастному (доля несовершеннолетних), партийному (доля коммунистов и комсомольцев), производственному признакам; вывод о тенденции повышения/снижения преступности в городе за отчётный период с объяснением причин; анализ мер борьбы с преступностью (структура и кадровый состав городского аппарата милиции, состояние охраны государственных объектов, воспитательная работа с молодёжью и т. д.) [5, ф. П-234, оп. 20, д. 9, л. 28-30]. Очевидна информативная ценность таких документов: выявление преступлений экономического характера вполне доступно. Архивные документы такого рода позволяют проследить динамику в первую очередь таких видов экономических преступлений, как кражи (государственного имущества, квартирные, карманные) и грабежи.

Важный срез общественных настроений жителей города представлен в таких документах, как информационные сообщения, составлявшиеся по материалам пункта Военной цензуры, по запросам горкома ВКП(б). В частности, среди них встречаются выдержки из писем с жалобами жителей города на воровство и грабежи: «Здесь уже очень многие картошку выкопали, хотя она ещё не дозрела, ожидать нельзя очень тащат, воровство ужасное. Каждую ночь новое происшествие. Бандитизм ужасный. В общежитиях наших и дневальная, и уборщица, но всё равно покражи беспрерывно происходят, страшно жить» [5, ф. П-234, оп. 18, д.14, л. 104-105]. Части писем, содержавшие жалобы, как правило, незамедлительно изымались в пунктах военной цензуры. Конкретная информация о нарушениях и преступлениях, содержавшаяся в них, доводилась до секретарей горкома партии: НКВД совместно с партийными работниками должны были проверять указанные факты и принимать необходимые меры по их устранению [3, с. 45].

Исследовательский интерес представляют архивные документы о работе Отделов рабочего снабжения при промышленных предприятиях (ОРСов), которые призваны были улучшить продовольственное обеспечение работников предприятия в экстремальных условиях нехватки продовольствия в период военного времени. ОРС ММК был одним из крупнейших в стране. Но в условиях всеобщего дефицита и отсутствия чёткой системы учёта и контроля в ОРСах происходили хищения и разбазаривания продуктов питания. Так, прокурор г. Магнитогорска советник юстиции Н. Матвеев в апреле 1944 г. докладывал в горком ВКП(б) о ходе следствия над группой работников ОРСа ММК по обвинению в расхищении продуктов и продаже их не по назначению $[5, \phi$. П-234, оп. 19 , д. 95, л. $71-$ 75]. Дело было настолько показательным и резонансным, что о нём писали в журнале «Социалистическая законность» $[6$, с. 32].

Ряд документов позволяет проследить механизм работы народных судов: виды преступных деяний, сроки рассмотрения судебных дел, характер вынесенных приговоров (обвинительных, оправдательных, прекращённых дел, возвращённых дел), анализ недостатков в работе народных судов, их причин и мер по устранению. Статистические данные, представленные в таких материалах, позволя- 
ют определить долю рассмотренных преступных деяний экономического характера среди общего количества поступивших в народные суды дел за определённый период времени [5, ф. П-234, оП. 17, д. 88, л. 1-6].

Конечно, муниципальный архив Магнитогорска содержит меньше информации об экономической преступности военного периода, но можно обратить внимание на некоторые документы, пока не затронутые исследователями и не введённые в научный оборот. Это - фонды районных народных судов (ф. 108 и ф. 184), содержащие материалы конкретных судебных дел по таким видам преступлений, как скупка и перепродажа с целью наживы продуктовых и промышленных товаров (ст. 107 УК РСФСР); хищение денежных средств или личных вещей граждан, используя служебное положение (ст. 109, 111 УК РСФСР); хищение социалистической собственности с территории промышленных предприятий (ст. 162 УК РСФСР) [4, ф. 108, оп. 1, д. 169, 177, 178, 182; ф. 184. оп. 1, д. 1-18, 23]. Фрагментарная сохранность и бессистемность этого материала препятствует воссозданию полной картины экономической преступности в городе и не позволяет извлечь информацию статистического характера. Тем не менее, анализ материалов отдельных судебных дел даёт возможность исследователю выявить виды преступлений и особенности правоприменительной практики в военный период в промышленном городе глубокого тыла.

При работе с архивными документами исследователь сталкивается с проблемой атрибуции текстов. Значительная часть архивных документов военного времени напечатана с помощью печатной машинки на бумаге плохого качества, так что за долгие годы хранения печать выцветает и становится трудноразличимой. Многие материалы, хранящиеся в Магнитогорском городском архиве, рукописные, что затрудняет их чтение из-за особенностей почерка и выцветших чернил. Особая тщательность требуется от исследователя при прочтении фамилий, имён и названий населённых пунктов, поскольку в их написании много ошибок или опечаток, вызванных общей малограмотностью населения.

Одним из основных источников информации для сограждан в годы войны была городская газета «Магнитогорский рабочий». Материал о преступлениях экономического характера, как правило, помещался на последней странице городской газеты в виде заметки с описанием конкретного преступления с обнародованием фамилии осуждённого и приговором суда. Пик публикаций о преступлениях в городе пришёлся на вторую половину 1942-1943 гг. Чаще всего описывались такие виды преступлений, как подделка или хищение продуктовых карточек; покупка и перепродажа продуктовых и промышленных товаров (спекуляция); подмена и продажа комендантами общежитий казённого имущества; квартирные кражи; обмеры и обсчёты в столовых и магазинах; хищение вещей, собранных населением для нужд Красной Армии; воровство с общественных огородов [1]. Следует отметить, что информативность материалов периодической печати как исторического источника ограничивается их идеологизированностью и подцензурностью. Содержащаяся в газетных публикациях информация должна была, прежде всего, вселить в читателя уверенность в неотвратимости наказания за преступные деяния и в эффективности работы органов правопорядка в городе.

В целом, анализ состояния архивов и периодической печати продемонстрировал наличие обширной источниковой базы для исследования проблемы экономической преступности в Магнитогорске в период 1941-1945 гг., что отражено в документах, отложившихся в архивах различного уровня: федеральных, областных, муниципальных. Архивохранилища содержат богатые коллекции документов и материалов по проблемам экономической преступности периода Великой Отечественной войны: нормативно-правовые акты, отразившие государственную политику противодействия хозяйственным преступлениям, делопроизводственная документация партийных и государственных органов, материалы судебной и прокурорской практики, официальная статистическая отчётность, публикации массовой печати. Дополнить источниковую базу могут материалы местной периодической печати, но при их использовании необходимо учитывать идеологизированность и подцензурность прессы советского периода. Введение в научный оборот выявленных документов и материалов позволит глубже изучить тему экономической преступности военного периода и разрешить многие спорные вопросы в современной историографии.

\section{СПИСОК ИСТОЧНИКОВ И ЛИТЕРАТУРЫ}

1. Городская газета «Магнитогорский рабочий». 1941. 28 окт.; 1942. 12 февр., 16 мая, 4 и 30 июня, 3, 16, 20 и 24 окт., 13 нояб., 2, 15 и 16 дек.; 1943. 9 и 30 янв., 30 марта, 21 апр., 20 мая, 20 и 23 июня, 24 июля, 8 сент., 1 дек.; 1944. 22 марта, 9 апр., 10 и 20 мая; 1945. 1 апр.

2. Государственный архив Российской Федерации (ГАРФ). 
3. Любеикий A. E. Всестороннее обеспечение семей военнослужащих в годы Великой Отечественной войны (по материалам обращений граждан) // Гуманитарно-педагогические исследования. 2018. № 2. С. 42-49.

4. МКУ «Городской архив» г. Магнитогорска (МКУ «ГА» г. Магнитогорска).

5. Объединённый государственный архив Челябинской области (ОГА ЧО).

6. Пасс A. А. Экономическая преступность в годы Великой Отечественной войны (по страницам журнала «Социалистическая законность» 1941-1945 гг.) // Вестн. Южно-Урал. гос. ун-та. Сер.: Социально-гуманитар. науки. 2019. Т. 19. № 2. С. 29-34.

Поступила в редакцию 10.05.2019

Потёмкина Марина Николаевна, доктор исторических наук, профессор, заведующая кафедрой всеобщей истории ФГБОУ ВО «Магнитогорский государственный технический университет имени Г.И. Носова» 455000, Россия, Челябинская область, г. Магнитогорск, просп. Ленина, 38

E-mail: mpotemkina@mail.ru

\section{M.N. Potemkina \\ ECONOMIC CRIME IN MAGNITOGORSK DURING THE GREAT PATRIOTIC WAR: THE INFORMATION CAPACITY OF HISTORICAL SOURCES}

DOI: $10.35634 / 2412-9534-2019-29-4-656-659$

The sources on the history of economic crime during the Great Patriotic War are considered in this article. They relate to an important industrial rear town - Magnitogorsk. The documentary materials of central and local archives, as well as publications in the local press of the war period, containing information that can be used for scientific purposes to study the problems of economic crime in the Soviet rear under extreme conditions of war, are examined. The revealed materials contain statistical data, descriptions of various types of economic crimes, analysis of the factors of their reproduction, change in the legislative base of the state counteraction to crime. It was concluded that, despite the incomplete preservation and dispersion of documents in various archives and funds, the identified materials have a high informative value and their scientific use will contribute to the integrated disclosure of the problem of economic crime in a rear industrial city of strategic importance.

Keywords: historical source, economic crime, the Great Patriotic war, Magnitogorsk, archival document, periodical press.

\section{REFERENCES}

1. Gorodskaya gazeta "Magnitogorskiy rabochiy" [Magnitogorsk Worker]. 1941, October, 28; 1942, February, 12, May, 16, June, 4, 30, October, 3, 16, 20, 24, November, 13, December, 2, 15, 16; 1943, January, 9, 30, March, 30, April, 21, May, 20, June, 20, 23, July, 24, September, 8, December, 1; 1944, March, 22, April, 9, May, 10, 20; 1945, April, 1. (In Russian).

2. Gosudarstvennyj arhiv Rossijskoj Federacii (GA RF) [State Archive of the Russian Federation]. (in Russian, unpublished).

3. Lyubeckij A. E. Vsestoronnee obespechenie semey voennosluzhashchih v gody Velikoy Otechestvennoy vojny (po materialam obrashchenij grazhdan) [Military families complaints and pleas about public authorities work to provide their all-round support during The Great Patriotic War]. Gumanitarno-pedagogicheskie issledovaniya [Humanitarian and pedagogical Research], 2018, no. 2, pp. 42-49. (In Russian).

4. MKU “Gorodskoy arkhiv” Magnitogorska (MKU “GA” Magnitogorska) [“City Archive” of Magnitogorsk]. (in Russian, unpublished).

5. Ob'edinennyj gosudarstvennyj arhiv Chelyabinskoj oblasti (OGA ChO) [Joint State Archive of Chelyabinsk Region]. (in Russian, unpublished).

6. Pass A. A. Ekonomicheskaya prestupnost' v gody Velikoy Otechestvennoy vojny (po stranicam zhurnala "Socialisticheskaya zakonnost" 1941-1945 gg.) [Economic crime in the years of the Great Patriotic war (on the pages of the journal "Socialistic law" 1941-1945)]. Vestnik Yuzhno-Ural'skogo gosudarstvennogo universiteta. Seriya: Social'no-gumanitarnye nauki [Bulletin of South Ural State University. Series Humanities and Social Sciences], 2019, vol. 19 , no. 2, pp. 29-34.

Potemkina M.N., Doctor of History, Professor, Head of the Department of World History Magnitogorsk State Technical University named after G.I. Nosov

Lenin Avenue, 38, Magnitogorsk, Chelyabinsk region, Russia, 455000

E-mail: mpotemkina@mail.ru 